\title{
Lost and found: the science lost in World War II
}

\author{
Sven Thatje ${ }^{1}$
}

Received: 19 September 2017 / Accepted: 30 September 2017 / Published online: 9 October 2017

(C) Springer-Verlag GmbH Germany 2017

Academic publishing is closely tied to the societal events of its time. With its over 100 years in existence, The Science of Nature, formerly known as Naturwissenschaften (Thatje 2013), has been witnessing the turbulent changes of the 20 ies century including both World Wars. I have recently been made aware of a set of galley proofs of a manuscript by the academic scholar Gustav E.R. Schulze that had been rediscovered from the scholar's personal effects. The manuscript was due for publication in Naturwissenschaften in early 1945. Indeed, annotations of the galley proofs indicate that the proofs were established 13 October 1944, and that typesetting of the corrected set of proofs was initiated 12 January 1945 (Fig. 1). However, this work was never published. Publication of Naturwissenschaften ceased in October 1944, a few months before the end of World War II in May 1945. The publisher Springer was able to maintain its professional activities until late in the war, which is perhaps surprising, as Germany, at that time, suffered from widespread destructions of industrial sites fol- lowing air raids, and the publisher's main buildings in Berlin had been largely destroyed by an air raid at the end of 1943 (Götze 1994); since then, the logistics of maintaining a production line must have been challenging. Naturwissenschaften resumed publishing in January 1946.

It remains unclear how many scientific manuscripts ready for publication had been lost by Springer's Naturwissenschaften alone, and academic publishing in general, in the final period of World War II. The manuscript by Schulze will most likely not have been the only one; unfortunately, no data appear to have survived the period to support this analysis. Nevertheless, it may indeed be surprising for how long academic publishing in Germany was upheld and given the disastrous situations surrounding World War II.

I considered publishing the full set of galley proofs of Schulze's work; however, some pages were too damaged and too much information had been lost to reconstruct and present a complete story. His article and efforts, therefore, do unfortunately remain lost to science!

Sven Thatje

svth@noc.soton.ac.uk

Ocean and Earth Science, National Oceanography Centre Southampton, University of Southampton, European Way, Southampton SO14 3ZH, UK 


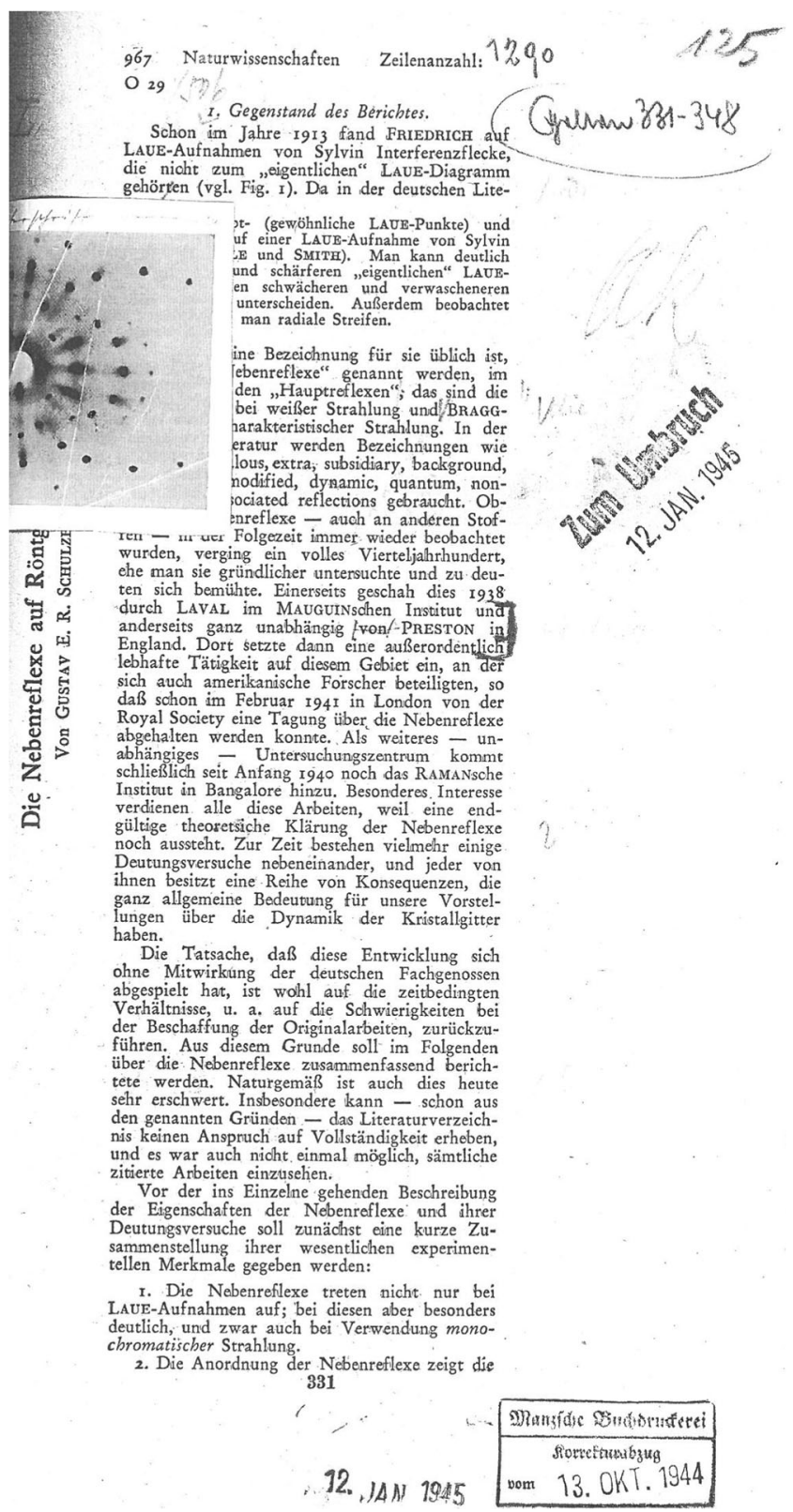

Fig. 1 Page 1 of the annotated galley proofs of a manuscript by Gustav E.R. Schulze, entitled "Die Nebenreflexe von Röntgenaufnahmen" (in German)
Acknowledgements Thanks are due to Professor Peter Paufler for rediscovering the manuscript by Gustav E.R. Schulze.

\section{References}

Götze H (1994) Der Springer Verlag. Stationen seiner Geschichte. Teil II 1945-1992. Springer-Verlag Berlin Heidelberg ISBN 3-540-56691-0 Thatje S (2013) Celebrating 100 years: happy birthday, Naturwissenschaften! Naturwissenschaften 100:1. https://doi.org/10.1007/s00114-012-1000-7 